\title{
A survey of canine filarial diseases of veterinary and public health significance in India
}

\author{
Puteri Azaziah Megat Abd Rani ${ }^{{ }^{*}}$, Peter J Irwin², Mukulesh Gatne ${ }^{3}$, Glen T Coleman', Linda M Mclnnes², \\ Rebecca J Traub ${ }^{1}$
}

\begin{abstract}
Background: Dirofilaria spp., Acanthocheilonema spp. and Brugia spp. have all been reported in Indian dogs. In previous studies, diagnosis was made by morphological identification only. This is the first geographically stratified cross-sectional study in India to determine the prevalence and geographical distribution of canine filarial species of veterinary and public health importance, using a combination of conventional and molecular diagnostic techniques.

Results: A total of 139 from 525 dogs (26.5\%; 95\% Cl 22.7, 30.3) were positive for microfilariae. The most common species of canine filaria identified in this study was A. reconditum (9.3\%) followed by D. repens (6.7\%) and D. immitis (1.5\%). Three out of 525 dogs were found to have mixed infections on PCR. The morphological and molecular evidence on the sequence of the 185 gene and phylogenetic analysis of the ITS-2 region provided strong evidence that the canine microfilariae discovered in the Himalayan city of Ladakh belong to a novel species of Acanthocheilonema. Two dogs in Ladakh were also found to have mixed infections of the novel species described above and a unique microfilaria which morphologically resembled Microfilaria auquieri Foley, 1921.

Conclusions: At least six species of filarial nematode are now known to infect dogs in India, two of which were reported for the first time in this study. The study also confirms and extends the geographical distribution of canine heartworm (D. immitis) which overlaps with $D$. repens, emphasising the importance for veterinary clinicians and diagnostic laboratories to utilise immunodiagnostic tests that will not cross-react between those two filarial species. From a public health viewpoint, the distribution and prevalences of these nematodes warrant an appropriate prophylaxis to be administered to dogs.
\end{abstract}

\section{Background}

Filariasis in dogs is caused by several species of filariids. Dirofilaria immitis, the most pathogenic canine filarid is responsible for heartworm disease in dogs. Both $D$. repens and Acanthocheilonema spp. develop into adult worms in the subcutaneous tissue resulting in skin nodules. Adults of Brugia spp. are usually recovered from the mandibular, retropharyngeal and axillary lymphatics. Most infections with D. repens, Acanthocheilonema spp. and Brugia spp. are of minimal veterinary clinical significance, however all canine filariae have the potential to infect humans and remain important from a public health perspective $[1,2]$.

\footnotetext{
* Correspondence: puteri.megatabdrani@uqconnect.edu.au
'School of Veterinary Science, The University of Queensland, Queensland

* Correspondence: puterimegatabdrani@uqconnect.edu.au
${ }^{1}$ School of Veterinary Science, The University of Queensland, Queensland 4072, Australia
}

Diagnostic methods for filarial infections include isolation of adult worms followed by morphological identification, morphological observation of circulating microfilariae by stained blood smears, direct wet smears, modified Knott's technique and the Wylie's filtration technique [2,3]. Histochemical or immuno-histochemical staining of circulating microfilariae has also been performed [4-6]. Detection of circulating antigen with commercial test kits is currently available and widely used for $D$. immitis $[7,8]$. Molecular diagnostic approaches are also increasingly utilised for research and surveillance purposes $[9,10]$.

In India, Dirofilaria spp., Acanthocheilonema spp. and Brugia spp., have all been reported in dogs [6,11-13]. Previous reports on filarial infections in India are summarised in Table 1. Based on these limited number of studies, it is currently accepted that D. immitis is 
Table 1 Previous reported prevalences of canine filarial species in different location in India

\begin{tabular}{|c|c|c|c|c|c|}
\hline & \multicolumn{3}{|c|}{ Northeast India } & \multicolumn{2}{|c|}{ Southern India } \\
\hline & $\begin{array}{c}\text { Mizoram } \\
n=240\end{array}$ & $\begin{array}{c}\text { Orissa } \\
n=7\end{array}$ & $\begin{array}{c}\text { Kolkata } \\
\mathrm{n}=3200\end{array}$ & $\begin{array}{c}\text { Kerala } \\
n=160\end{array}$ & $\begin{array}{c}\text { Karnataka } \\
n=400\end{array}$ \\
\hline nitis & $34 \%$ & $57 \%$ & $3 \%$ & $0 \%$ & $0 \%$ \\
\hline Dirofilaria repens & $0 \%$ & $14 \%$ & $0 \%$ & $7 \%$ & $21 \%$ \\
\hline
\end{tabular}

*Data obtained from $[52,29,24,30,6]$

geographically restricted to India's north-east and $D$. repens to India's south, with an overlapping area centrally. There are no reports of $D$. immitis occurring elsewhere in India, despite anecdotal evidence to suggest its occurrence in Delhi (Sharma, personal communication, July 2008, Delhi). This accepted view is questionable as competent mosquito vectors for $D$. immitis, belonging to the genera Culex, Aedes and Anopheles, that also happen to act as vectors for $D$. repens, are present all over India [14]. Moreover, a case of human pulmonary dirofilariasis due to D. immitis was reported in Mumbai in 1989 [15], which casts further doubt on its currently accepted geographical distribution. Recently, 16 out of 75 microfilaraemic dogs were shown to harbour $B$. malayi by researchers at the Kerala Agricultural University's College of Veterinary and Animal Sciences using morphological and immunodiagnostic criteria [13]. However, since B. ceylonensis is endemic in Sri Lanka this finding needs to be confirmed using PCR as the microfilariae cannot be differentiated morphologically from $B$. malayi and it is likely the ELISA test crossreacts among Brugia spp. [16].

In previous reported studies, microfilarial identification relied on morphological assessment only. Despite the availability of published measurements of various microfilariae, the inadequacy of morphological diagnosis was demonstrated by Rishniw and colleagues (2006) [9] when microfilariae initially identified as $A$. reconditum were later determined to be $D$. immitis by molecular methods. Morphological identification of microfilariae not only requires experienced personnel but it may be difficult to detect multiple infections with more than one species of filarial worms [2].

A geographically stratified cross-sectional study was undertaken to determine the prevalence and geographical distribution of canine filarial species of veterinary and public health importance in India using a combination of conventional and molecular diagnostic techniques.

\section{Methods}

\section{Study site}

India features a wide range of climatic zones, ranging from montane (cold, wet alpine regions) and semi-arid regions to the wet tropics. The ecology of vectors of medical and veterinary importance (and therefore the diseases they transmit) is highly dependent on climate [17]. The study was stratified to include four climatic zones of India. The locations of the places sampled represent a unique climatic condition of their own, based on information produced by The World Meteorological Organization [18]. Ladakh in India's far north (3000 m altitude), experiences a temperature that rarely exceeds $27^{\circ} \mathrm{C}$ in summer, while in winter temperatures drop to minus $20^{\circ} \mathrm{C}$. Mumbai's climate can be described as tropical with a high level of humidity. The mean average temperature for Mumbai ranges from $16^{\circ} \mathrm{C}$ during winter to $30^{\circ} \mathrm{C}$ in summer. The climate of Delhi is a monsoon-influenced humid subtropical climate with average temperatures range from $7^{\circ} \mathrm{C}$ during its dry winter to $39^{\circ} \mathrm{C}$ in summer. Sikkim's climate can be described as subtropical highland with mild temperatures range from $25^{\circ} \mathrm{C}$ in summer to $4^{\circ} \mathrm{C}$ in winter [19].

To facilitate the fieldwork, collaborations were established with Vets Beyond Borders, Jeevaashram, Krishnaashram, Bombay Veterinary College and In Defence of Animals India. These organisations allowed us access to stray and refuge dogs through their Animal Birth Control $(A B C)$ and rabies vaccination programs. In these programs stray dogs are impounded, vaccinated, surgically neutered and released back to their original location [20]. The purpose of this program is to stabilise the street dog population and to help control the spread of rabies. Capillary and whole blood samples were collected from 525 dogs from four different cities (Figure 1 ), namely Gangtok and Jorethang in Sikkim ( $\mathrm{n}=101)$, Ladakh $(\mathrm{n}=100)$ in Jammu and Kashmir, Delhi $(\mathrm{n}=$ $162)$ and Mumbai $(n=162)$. Blood samples were subjected to normal-thin and buffy-coat smears, air-dried and fixed in 100\% ethanol and later stained with Giemsa for microscopic screening. Whole blood samples were also applied onto QIAcard FTA ${ }^{\oplus}$ Four Spots (Qiagen) for molecular-based screening later.

\section{Microscopic examination of blood films}

Stained blood films were examined under $\times 200$ and $\times 400$ objective lens for microfilariae. The microfilariae were measured using Olympus $\mathrm{BH}-2$ microscope (Japan) calibrated eye micrometer and photographed using Olympus DP12 digital microscope camera (Japan).

\section{DNA extraction of adult D. immitis and blood from QIAcard FTA ${ }^{\oplus}$}

DNA from an adult worm of $D$. immitis (courtesy of Murdoch University) was extracted using the tissue sample protocol of the MasterPure DNA purification kit (Epicentre) according to the manufacturer's instructions and utilised as a positive control for this study. 


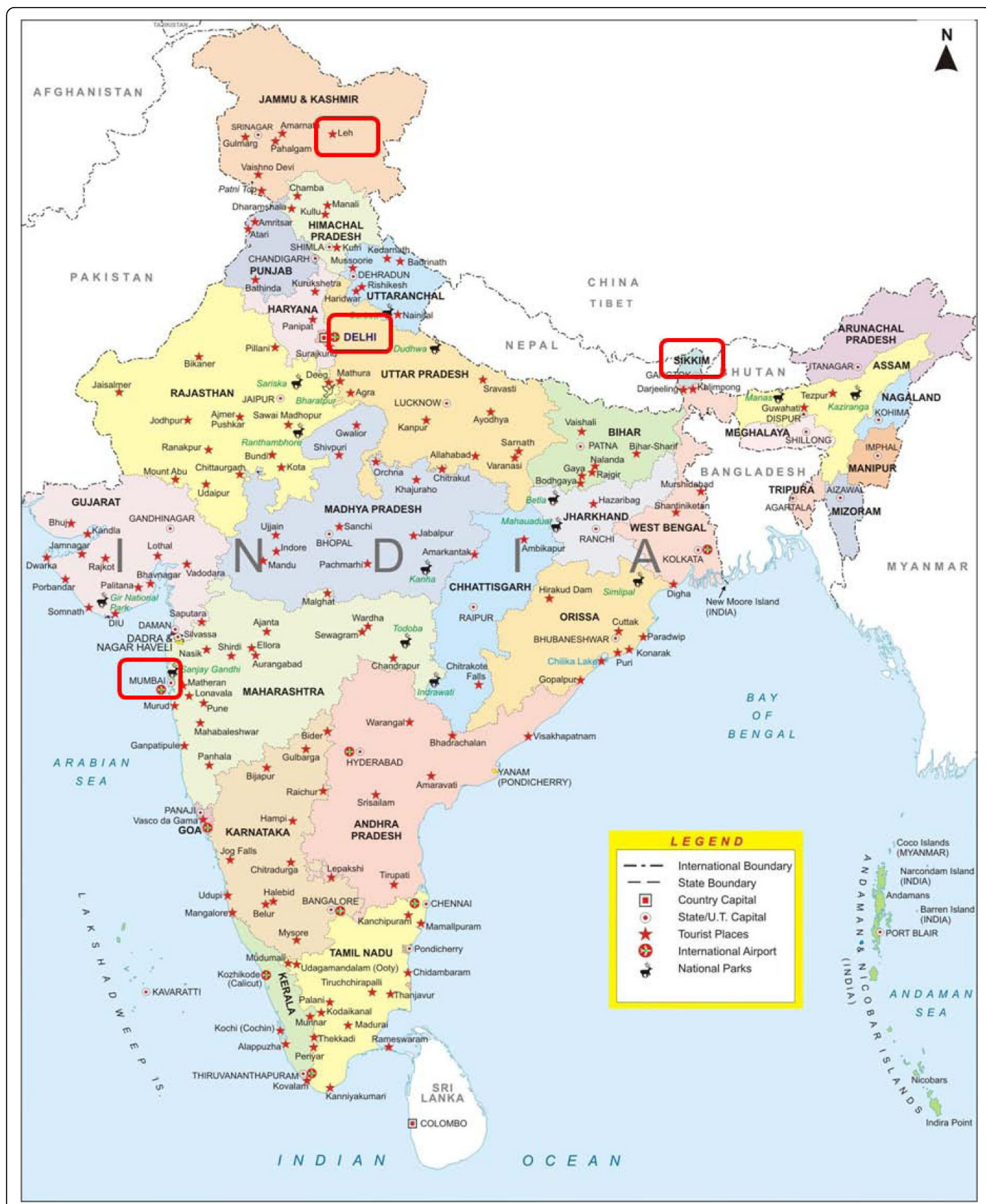

Figure 1 Political map of India. Areas outlined in red rectangles indicate sampling locations. 
Table 2 Primer sequences used to amplify PCR products from filarial and canine blood samples [9].

\begin{tabular}{|c|c|c|c|c|}
\hline Primer pair & Primer sequence & Gene target & Product origin & Product size (based-pairs) \\
\hline$\overline{D I D R-F 1}$ & AGT GCG AAT TGC AGA CGC ATT GAG & 5.8S-ITS2-28S & D. immitis & 542 \\
\hline \multirow[t]{5}{*}{ DIDR-R1 } & AGC GGG TAA TCA CGA CTG AGT TGA & & D. repens & 484 \\
\hline & & & B. malayi & 615 \\
\hline & & & B. pahangi & 664 \\
\hline & & & A. reconditum & 578 \\
\hline & & & A. dracunculoides & 584 \\
\hline
\end{tabular}

Product size and species of filarial nematodes amplified are also reported.

Approximately $500 \mu \mathrm{l}$ of blood from each animal was applied on QIAcard FTA ${ }^{\circledast}$ Four Spots (Qiagen) which were cut into two $\mathrm{cm}$ strips (vertically) and allowed to air dry. A modified DNA purification protocol for tissue samples using the MasterPure DNA purification kit (Epicentre) was used to extract DNA from FTA cards. A $2 \mathrm{~cm}^{2}$ piece of dried FTA card impregnated with a blood sample was cut into small pieces using a sterile scalpel blade on a clean microscope slide and placed in a $1.5 \mathrm{ml}$ microcentrifuge tube. One $\mu \mathrm{l}$ of Proteinase $\mathrm{K}$, $150 \mu \mathrm{l}$ tissue lysis buffer and $150 \mu \mathrm{l}$ phosphate buffer saline were added to the FTA card sample and incubated overnight at $65^{\circ} \mathrm{C}$. The lysed sample was then cooled on ice for 5 minutes, $175 \mu \mathrm{l}$ of MPC protein precipitation reagent added and the sample centrifuged at 6, $800 \mathrm{~g}$ for 10 minutes. Following centrifugation the supernatant was transferred into a clean $1.5 \mathrm{ml}$ tube and $500 \mu \mathrm{l}$ of isopropanol added. The sample was then inverted 30-40 times to promote DNA precipitation, centrifuged at $6,800 \mathrm{~g}$ for 10 minute and the supernatant removed carefully so as to not dislodge the DNA pellet. DNA pellet was washed twice with $70 \%$ ethanol. The sample was air dried for 5 minute to remove any remaining ethanol before the DNA pellet was resuspended in $20 \mu \mathrm{l}$ of TE buffer.

\section{PCR assays and DNA sequencing}

A single-step multiplex PCR targeted at amplifying the internal transcribed spacer-2 region of ribosomal DNA developed by Rishniw and colleagues (2006) [9] was utilised for molecular screening of canine filarial species in blood. Pan-filarial primers, forward: DIDR-F1 5'-AGT GCG AAT TGC AGA CGC ATT GAG-3' and reverse: DIDR-R1 5'-AGC GGG TAA TCA CGA CTG AGT TGA-3' were utilized to amplify and differentiate $D$. immitis, D. repens, $B$. malayi, B. pahangi, A. reconditum and $A$. dracunculoides. The PCR assay was carried out in a final volume of $25 \mu$ l containing $1 \times$ PCR buffer, $1.5 \mathrm{mM} \mathrm{MgCl}_{2}, 200 \mu \mathrm{M}$ dNTPs, $0.5 \mu \mathrm{M}$ of each primer, $1 \mathrm{U}$ of Taq polymerase and $1 \mu \mathrm{l}$ of DNA template. The PCR procedure was executed according to Rishniw et al. (2006). The PCR products were run on a $2 \%$ agarose gel in $1 \times$ TAE buffer at $100 \mathrm{~V}$ and visualised using Geldoc
(Biorad). The anticipated product sizes of each species of microfilaria are listed in Table 2.

PCR products from $30 \%$ of all positive samples were purified using Qiagen spin columns (Qiagen). When a multiple-band product was obtained, target bands were excised and purified with Qiaquick Gel Extraction kit (Qiagen) prior to DNA sequencing. DNA sequencing was performed using an ABI 3130xl Genetic Analyzer (Applied Biosystems) with Big Dye 3.0 chemistry, after which sequences were edited and assembled using Finch TV (Geospiza Inc.).

\section{Primer design for $18 \mathrm{~S}$ gene and amplification}

A nested PCR was designed to amplify a partial region of the $18 \mathrm{~S}$ rDNA of canine filarial species. Sequences of the near complete $18 \mathrm{~S}$ rDNA of $B$. malayi [GenBank: AF036588], Wuchereria bancrofti [GenBank: AF227234] D. immitis [GenBank: AF036638] and Dipetalonema sp. [GenBank: DQ531723.1] were aligned using Clustal W http://align.genome.jp/ and an external and an internal set of primers (Table 3) were designed to amplify an approximately 800 bp and 700 bp product, respectively.

The PCR assay was carried out in a volume of $25 \mu \mathrm{l}$ containing $1 \times$ PCR buffer (Qiagen), $1.5 \mathrm{mM} \mathrm{MgCl}_{2}, 200$ $\mu \mathrm{M}$ of each dNTP, $0.5 \mu \mathrm{M}$ of each of the forward and reverse primers, $1 \mathrm{U}$ of Taq DNA polymerase (Qiagen) and $1 \mu \mathrm{l}$ of extracted DNA. Five microlitres of Q-solution (Qiagen) was also added to optimise the PCR. The PCR conditions of both primary and secondary PCR are as follows: an initial activation step at $94^{\circ} \mathrm{C}$ for 2 min was followed by 35 cycles of amplification $\left(94^{\circ} \mathrm{C}\right.$ for $30 \mathrm{~s}, 56^{\circ} \mathrm{C}$ for $30 \mathrm{~s}$ and $72^{\circ} \mathrm{C}$ for $30 \mathrm{~s}$ ) followed by a final extension

Table 3 External and internal primer sets for the amplification of a partial region of the $18 \mathrm{~S}$ gene of most filarial species.

\begin{tabular}{ll}
\hline Primer name & Sequence $\left(\mathbf{5}^{\prime}\right.$ - $\mathbf{3}^{\prime}$ ) \\
\hline PAFilariaF1 (external) & GGTGAACCGCGAACGGCTC \\
PAFilariaR1 (external) & CCGTCCCTCTTAACCATTATC \\
PAFilariaF2 (internal) & CTATAATGTACTTGATGTTGATATC \\
PAFilariaR2 (internal) & CCATGCACGAGTATTCAGGCA \\
\hline
\end{tabular}


step of $72^{\circ} \mathrm{C}$ for $7 \mathrm{~min}$. The template for the secondary PCR amplification consisted of $1 \mu \mathrm{l}$ of amplicon from the primary amplification.

\section{Phylogenetic analyses}

Neighbour joining analyses were conducted with Tamura-Nei parameter distance estimates and trees constructed using Mega 4.1 software. Bootstrap analyses were conducted using 1000 replicates.

\section{Results}

Out of the 525 dogs examined for circulating microfilaria, 27 (5.1\%; 95\% CI 3.3, 7.0) were positive using microscopic screening and 139 (26.5\%; 95\% CI 22.7, 30.3) confirmed for at least one filarial species by PCR. The most common species of canine filarial parasite identified in this study was $A$. reconditum followed by $D$. repens and $D$. immitis. The prevalence and geographical distribution of canine filarial species using both morphology and multiplex PCR are summarised in Table 4.

\section{Morphology identification}

All microfilariae found in this study except for those identified from dogs in Ladakh could be identified based on previously described and published morphological criteria. In Ladakh, 13 dogs were found to harbour unsheathed microfilariae (Figure 2) with an average length of $165 \mu \mathrm{m}$ (range $130 \mu \mathrm{m}$ to $180 \mu \mathrm{m}$ ), that did

Table 4 The prevalences of canine filarial species in different cities in India by PCR and microscopy (in parentheses)

\begin{tabular}{|c|c|c|c|c|c|}
\hline & $\begin{array}{c}\text { Delhi } \\
n=162\end{array}$ & $\begin{array}{l}\text { Mumbai } \\
\mathrm{n}=162\end{array}$ & $\begin{array}{c}\text { Sikkim } \\
n=101\end{array}$ & $\begin{array}{l}\text { Ladakh } \\
n=100\end{array}$ & $\begin{array}{c}\text { Overall prevalence } \\
n=527\end{array}$ \\
\hline Dirofilaria immitis & $4.3 \%(0 \%)$ & $0 \%(0 \%)$ & $1 \%(0 \%)$ & $0 \%(0 \%)$ & $1.5 \%(0 \%)$ \\
\hline Dirofilaria repens & $4.9 \%(0 \%)$ & $16.7 \%(8 \%)$ & $0 \%(0 \%)$ & $0 \%(0 \%)$ & $6.6 \%(2.2 \%)$ \\
\hline Acanthocheilonema reconditum & $22.2 \%(0.6 \%)$ & $4.3 \%(1.2 \%)$ & $5.9 \%(0 \%)$ & $0 \%(0 \%)$ & $9.3 \%(0.6 \%)$ \\
\hline Novel spp. & $0 \%(0 \%)$ & $0 \%(0 \%)$ & $0 \%(0 \%)$ & $48 \%(13 \%)$ & $9.1 \%(2.5 \%)$ \\
\hline Microfilaria auquieri & $0 \%(0 \%)$ & $0 \%(0 \%)$ & $0 \%(0 \%)$ & $0 \%(2 \%)$ & $0 \%(0.4 \%)$ \\
\hline
\end{tabular}

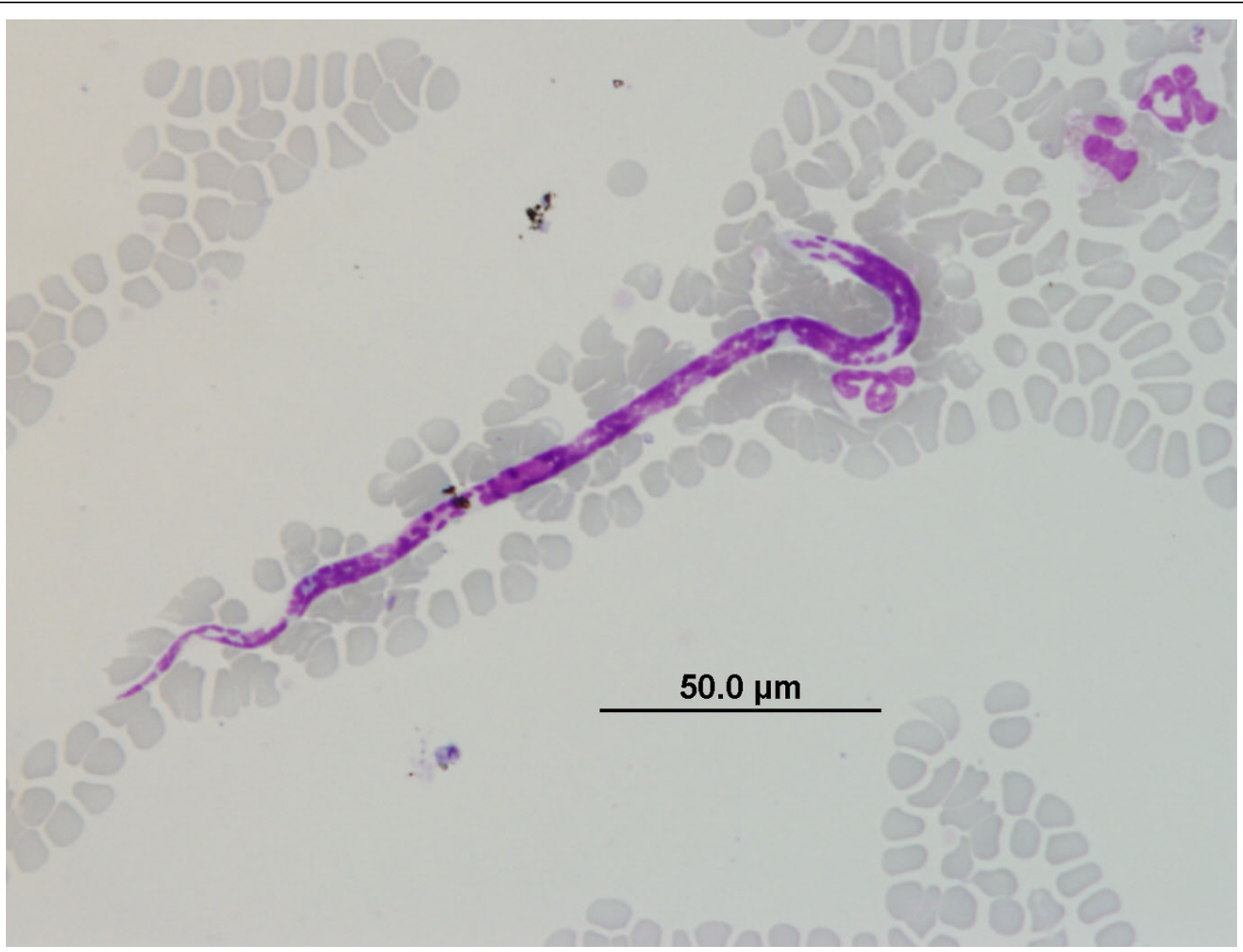

Figure 2 Unidentified microfilaria observed in Giemsa blood smears of dogs from Ladakh 
Table 5 Measurements of microfilaria recorded by various author ${ }^{a}$

\begin{tabular}{llll}
\hline Filarial species & Special features of microfilaria & $\begin{array}{l}\text { Microfilaria } \\
\text { Length }(\boldsymbol{\mu m})\end{array}$ & Width $(\boldsymbol{\mu}$ m) \\
\hline $\begin{array}{l}\text { Dirofilaria immitis } \\
\text { Dirofilaria repens }\end{array}$ & Unsheathed, tapered head, relatively straight tail & $218-329$ & $5.4-6.2$ \\
Acanthocheilonema reconditum & Unsheathed, round curved body, cephalic hook, blunt anterior end & $283-360$ & $7.1-8.3$ \\
Acanthocheilonema dracunculoides & & $195-270$ & $4-4.5$ \\
Cercopithifilaria grassi & & 567 & Not available \\
Microfilaria auquieri & Unsheathed & $58-102$ & Not available \\
Microfilaria ochmanni & Sheathed & 320 & Not available \\
Brugia malable & Sheathed, cephalic space: $6.3-6.7 \mu \mathrm{m}$ & $254-234$ & $5.99-7.99$ \\
Brugia pahangi & Sheathed, cephalic space: $6.4 \mu \mathrm{m}$ & $200-189$ & $4-5$ \\
Brugia ceylonensis & Sheathed, blunt tail, cephalic space: $6.3-6.7 \mu \mathrm{m}$ & $220-275$ & Not available \\
\hline
\end{tabular}

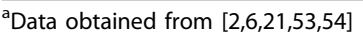

not match the length of previously described canine microfilariae (Table 5). Two dogs in Ladakh were also found to have mixed infections of the unidentified microfilaria described above and another microfilaria of an unusual appearance (Figure 3) which was identified morphologically and presumed as Microfilaria (Mf.) auquieri, a species previously described by Foley [21] and Rioche [22] in Algeria, North Africa. Further analyses with regard to the genetic identity of the unidentified canine microfilariae in Ladakh were conducted using the $18 \mathrm{~S}$ and ITS-2 genes.

\section{Single-step multiplex PCR}

Out of 525 samples, 139 produced amplicons corresponding to $D$. immitis, D. repens or A. reconditum. Three out of 527 dogs were found to have mixed infections based on the amplicon sizes; one from the city of Mumbai with $D$. repens and $A$. reconditum, and two from the city of Delhi with $D$. immitis and $A$. reconditum, and $D$. immitis with $D$. repens. Two samples from Ladakh which found to have mixed infections by microscopic screening with presumably $M f$. auquieri, only produced a single amplicon corresponds to A. reconditum. All PCR products amplified and sequenced at the ITS-2 region, except those from Ladakh as well as $A$. reconditum isolates from Delhi and Mumbai had their multiplex PCR results confirmed with published sequences for D. immitis from Mizoram, India [GenBank: EU087699], D. repens from Kerala, India [GenBank: FJ717410] and A. reconditum from Taiwan [GenBank: AF217801] with 99-100\% homology on the basic local alignment search tool, BLASTn http://blast. ncbi.nlm.nih.gov/Blast.cgi.

Acanthocheilonema reconditum isolates from Delhi and Mumbai displayed $95 \%$ and $90 \%$ homology to the published ITS-2 sequence for $A$. reconditum from Taiwan [GenBank: AF217801]. Sequences for the ITS-2 region of Acanthocheilonema isolates from each city;
Delhi, Mumbai and Ladakh were submitted to GenBank under accession numbers GU593976, GU593978 and GU593978, respectively.

\section{Genetic characterisation of unidentified canine microfilaria species}

Clear and readable sequences spanning a 441 bp region of the SSU rDNA gene were obtained from a single Ladakhi isolate of the unidentified species of canine microfilaria. These were aligned and compared with previously published sequences of closely related filariid species B. malayi [GenBank: AF036588], Loa loa [GenBank DQ094173], W. bancrofti [GenBank: AY843436], A. vitae [GenBank: DQ094171], Onchocerca cervicalis [GenBank: DQ094174], Setaria digitata [GenBank: DQ094175] and D. immitis [GenBank: AF182647] using Clustal W (BioEdit v 7.0.5.3). Thelazia lacrymalis [GenBank: DQ503458] was used as an outgroup [23]. Although bootstrap support was low for the differentiation of all genera of filariid, the unidentified microfilariae isolated from dogs in Ladakh were distinctly placed within the same clade as $A$. vitae (Figure 4).

ITS-2 sequences of Acanthocheilonema were found to have identical sequence homology within the same geographical area. Sequences of six of the unidentified microfilaria isolates from Ladakh, two isolates of $A$. reconditum from Mumbai and Delhi and a single isolate from Sikkim, together with GenBank reference sequences of canine filarial species $A$. reconditum [GenBank: AF217801], A. dracunculoides [GenBank: DQ018785] were compared and aligned with a using Clustal W (BioEdit v 7.0.5.3).

The topology of the unrooted phenogram recognises five major groups within the genus Acanthocheilonema, which encompassed $A$. reconditum from Taiwan/Sikkim, A. reconditum from Delhi, $A$. reconditum from Mumbai, Acanthocheilonema isolates from Ladakh and A. dracunculoides as separate groups. Isolates from Mumbai 


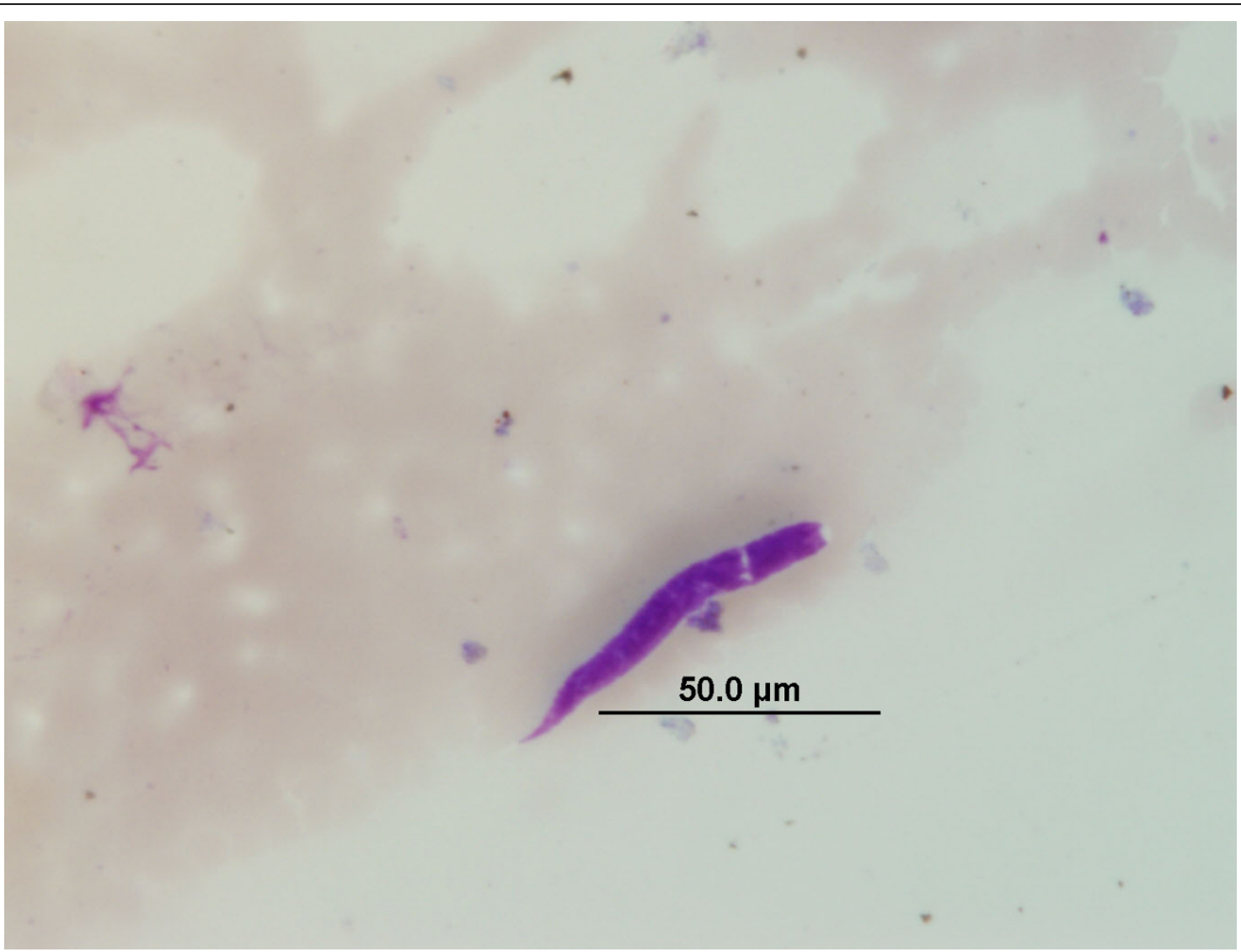

Figure 3 Microfilaria observed in Giemsa blood smears of dogs from Ladakh, India which conform to the morphological descriptions of Microfilaria auquieri Foley, 1921.

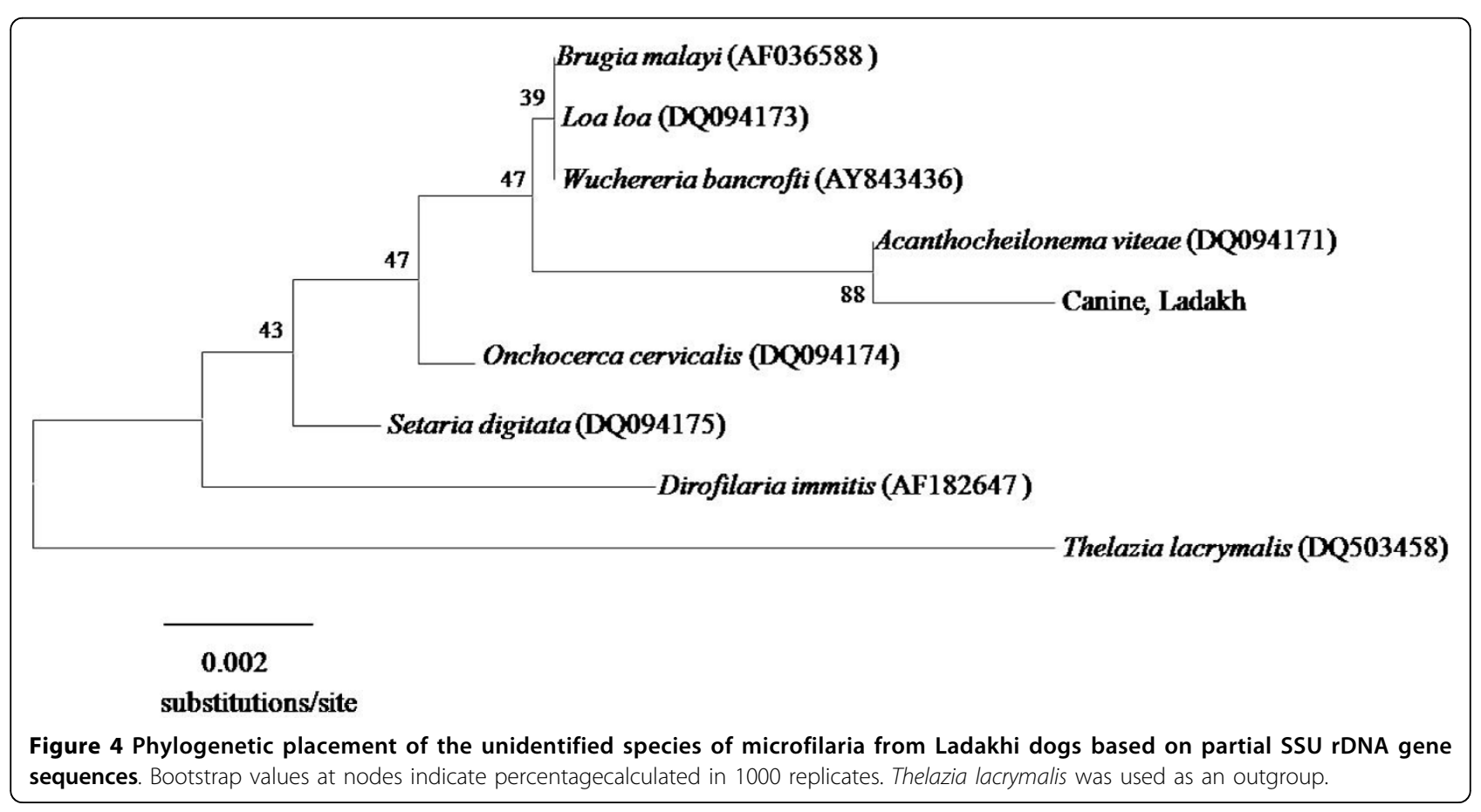




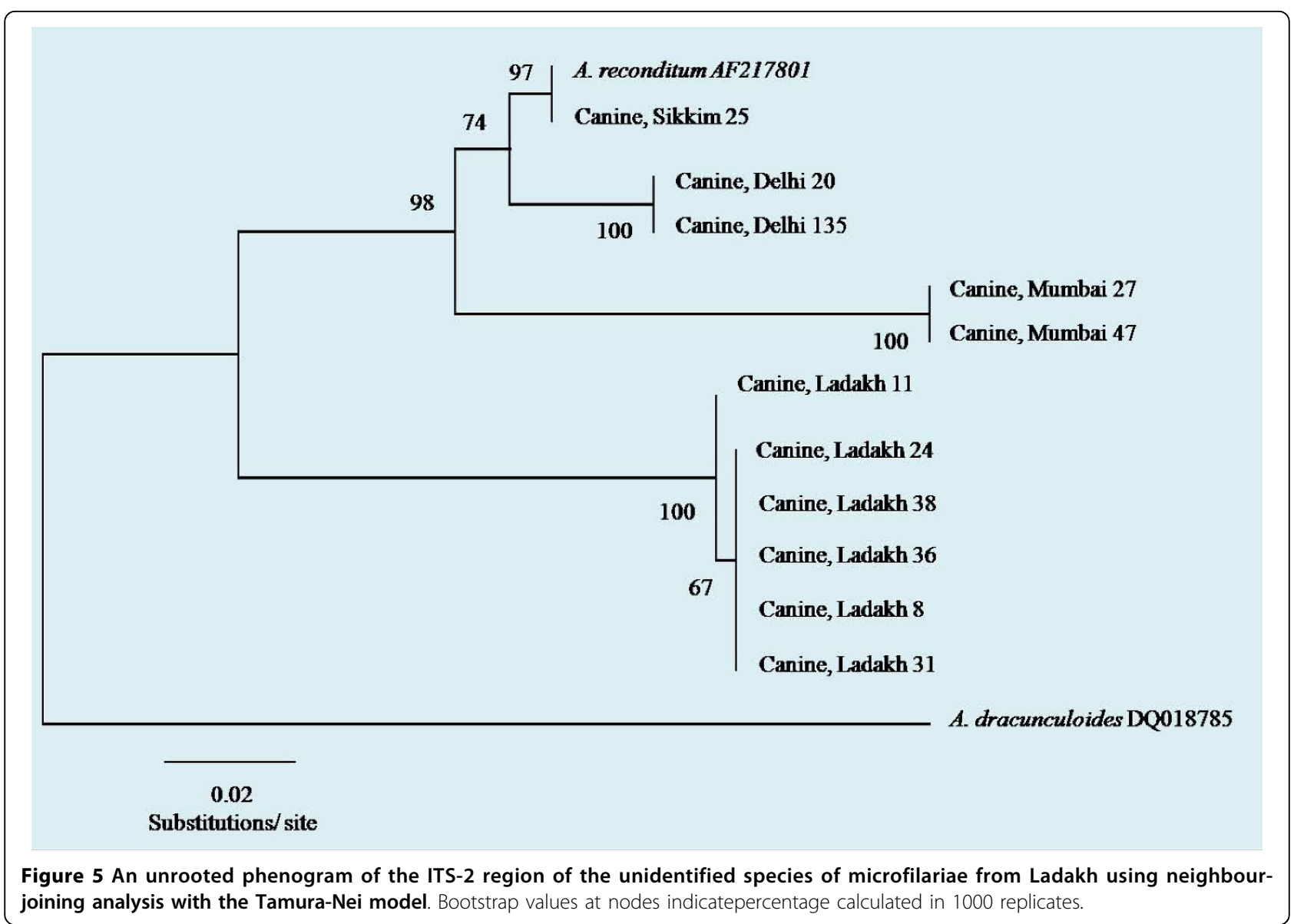

Table 6 Distance matrix showing the nucleotide difference among ITS-2 gene sequences for microfilaria isolated from dogs from Delhi, Mumbai, Sikkim and Leh with reference sequences from GenBank for $A$. reconditum [GenBank: AF217801] and $A$. dracunculoides [GenBank: DQ018785].

A. dracunculoides_DQ018785

A. reconditum_AF217801 0.19

Canine, Delhi isolate (A.r) $\quad 0.20 \quad 0.03$

$\begin{array}{llll}\text { Canine, Ladakh isolate } & 0.22 & 0.11 & 0.13\end{array}$

$\begin{array}{lllll}\text { Canine, Sikkim isolate (A.r) } & 0.19 & 0.00 & 0.03 & 0.11\end{array}$

$\begin{array}{llllll}\text { Canine, Mumbai isolate (A.r) } & 0.26 & 0.09 & 0.09 & 0.17 & 0.09\end{array}$

Isolates from the study designated 'A.r' in parentheses are those that morphologically resembled $A$. reconditum.

formed a sister group to $A$. reconditum isolates from Taiwan, Sikkim and Delhi. There was very strong bootstrap placement for all six Acanthocheilonema isolates from Ladakh into a distinct group from all isolates of $A$. reconditum as well as $A$. dracunculoides (Figure 5).

Genetic distances of the ITS-2 region between $A$. reconditum and Acanthocheilonema isolates from Ladakh (11\%) and Mumbai (9\%) were similar to that between $A$. reconditum and A. dranunculoides (19\%)
(Table 6), whereas those between $A$. reconditum and isolates from Delhi were significantly less (3\%).

\section{Discussion}

This is the first comprehensive study that has utilised a combination of conventional and molecular techniques to determine the distribution and occurrence of canine filarial species in India. Despite anecdotal accounts of heartworm being present in Delhi, this study is the first to confirm its presence in that city, together with $D$. repens. This study is in agreement with previous reports $[6,11,24]$ demonstrating a low prevalence of microfilaraemia overall, and that the most common filarial species found in India are $A$. reconditum and $D$. repens. Despite the relatively limited geographical locations used in this study, our results also support the aforementioned hypothesis that canine heartworm is primarily confined to tropical and sub-tropical areas of northern India, but seems to be absent towards the south. This hypothesis is debatable since competent mosquito vectors for $D$. immitis are present throughout central and southern India. For example, Aedes albopictus [25-27], a competent vector for $D$. immitis is present in Maharastra, Karnataka and Pondicherry [28], and heartworm is yet to be 
reported in dogs from these areas where climate would support larval development within the mosquito vector. It is noteworthy however that the prevalence of all filarial species determined in the current study may still an underestimate of its true value due to false negative test results. The high prevalence of $D$. immitis by necropsy that was reported in eastern and central India cannot be disregarded $[29,30]$. Authors of these studies also mentioned that more than $30 \%$ of dogs positive for D. immitis had occult infections, which is in agreement with studies from Australia in the 1980s [31]. Several types of occult filarial infection in dogs have been documented: pre-patent infection, naturally occurring unisexual infection and immune-mediated clearance of microfilariae, a similar situation that exists also in human filariasis [3,32-34]. PCR has been shown to detect occult infections of Loa loa in humans [35,36], however a recent study by Duscher (2009) has shown that a minimum parasitaemia level of $6 \pm 0.43$ microfilariae per $100 \mu \mathrm{l}$ of blood on the FTA cards is need for detection of $D$. repens microfilariae by PCR detection [37]. The authors explain that it is hard to distribute large extracellular metazoan stages such as microfilariae on a filter paper, and this can therefore lead to false negative results for low parasitaemia infections. Furthermore, macrocyclic lactones such as ivermectin are known to possess microfilaricidal effects. Almost half the refuge dogs from Mumbai and Delhi sampled in this study had a history of receiving treatment with ivermectin for the control of gastrointestinal and ectoparasites. A recent study by Bazzocchi and colleagues [38] confirmed that with prolonged treatment of ivermectin, a significant decreased in circulating microfilariemia in dogs (less than 100 microfilariae $/ \mathrm{ml}$ ) occurred.

The most common filarial species found in dogs from this study are $A$. reconditum and $D$. repens. Most infections with $A$. reconditum and $D$. repens do not contribute to any clinical illness in dogs, but this is not the case in humans [1,2]. Dirofilaria repens causing subcutaneous nodules and sub-conjunctival infections in humans is now considered as a re-emerging zoonoses and it often leads to misdiagnosis of malignant tumours in endemic areas $[1,24]$. Although $D$. repens is endemic to a wide geographical area spanning Europe and Asia, human cases, often involving nodules in organs such as lungs, male genitals and female breast are most commonly reported from Italy and Sri Lanka [39]. With regard to Acanthocheilonema, only one human case has been reported in Australia, which involved the eye; the recovered worm morphological features were consistent with an unfertilised adult female $A$. reconditum [40]. Dirofilaria immitis infection in humans is rarely reported, but associated with pulmonary lesions or radiological coin lesions of the lung. The significance of $D$. immitis infection in human is the confusion and invariable radiological misdiagnosis of a primary or metastatic lung tumour, which usually leads to thoracotomy for open lung biopsy or wedge resection of the lung to obtain the correct diagnosis $[41,42]$. Sporadic reports of the immature heartworm in unusual locations such as the eye, mesentery, cerebral artery, spermatic cord and liver also exist [43-47]. To date, twelve cases of human subcutaneous dirofilariasis due to $D$. repens has been reported in southern India [24] and a single case of human pulmonary dirofilariasis due to D. immitis in Mumbai [15].

All microfilariae found in this study except for those identified from dogs in Ladakh could be identified based on previously described and published morphological criteria. Morphologic dimensions of the microfilariae genetically characterised as $A$. reconditum from Delhi, Mumbai and Sikkim matched previously documented measurements for $A$. reconditum. This was supported by molecular evidence to show that the isolates clustered within the $A$. reconditum group on phylogenetic analysis. Genetic distances of the ITS- 2 region between $A$. reconditum and isolates from Delhi were within the range expected for intra-species variation of different geographical populations. However genetic distances of the ITS-2 region between $A$. reconditum and isolates from Mumbai were within the range expected for separate species of the same genera. Different species of filarial nematodes are reported to vary in their degree of intra-species variation based on the ITS-2 gene [48], making this comparative analysis difficult to confirm. Future molecular epidemiological studies comparing the intra-species variation of Acanthocheilonema spp. in different geographical locations at multiple loci is necessary to confirm this hypothesis. This finding is in contrast to the situation discovered with the microfilariae found to infect nearly half the dogs in Ladakh. Morphologically, the length of these latter microfilariae did not match any of the documented or known species of canine filariae. Molecular evidence based on the phylogenetic analysis of the $18 \mathrm{~S}$ and ITS- 2 regions provided strong evidence to show that the canine microfilariae found in Ladakh belong to a novel species of Acanthocheilonema. Genetic distances between this novel species and $A$. reconditum were within the range expected for separate species of the same genera. We propose that in the interim, this new species of microfilaria be designated Acanthocheilonema ladakhii until further and more detailed morphological, molecular and clinicpathological studies are undertaken to describe and name this novel species of canine filarial parasite and ascertain its veterinary significance.

This study also presents the first report of what we presume to be $M f$. auquieri in India and this serendipitous re-encounter with this filarial species after 50 years is of 
great parasitological interest. Although previously reported in stray dogs of Algeria, there is still much to be discovered about this enigmatic parasite. The adult form of $M f$. auquieri is not yet known as attempts to search for the adult parasite failed despite a systematic postmortem by the early French researchers [22]. It is interesting to note also that almost all dogs in Ladakh, and a small proportion in Delhi, were found infested with a species of blood-sucking fly (authors' personal observation), identified as Hippobosca longipennis syn. capensis Fabricius, 1805 [49], which is known to be an intermediate host and vector of $A$. dracunculoides [50]. Our findings in Ladakh have prompted us to speculate whether this same Hippobosca fly is also the vector/intermediate host for Mf. auquieri or whether it is just mere co-incidence that this fly also happens to be common in Algeria where $M f$. auquieri was first reported [49].

As a side note the authors would like to add that the application of blood samples to filter paper-based technology, such as the FTA cards used in this study, allow for the rapid and safe dispatch of samples to diagnostic facilities capable of PCR-based diagnosis, with the added advantage of providing an archival potential. However, using this technique in humid regions can result in fungal contamination of the blood-impregnated filter paper as we have experienced during this study. A careful drying process of the papers is therefore recommended to prevent this problem from occurring.

\section{Conclusion}

At least six species of filarial parasite are now known to infect dogs in India, two of which were reported for the first time in this study, namely Mf. auquieri and a novel species of Acanthocheilonema, both of which were discovered in the Himalayan city of Ladakh. The study also confirms and extends the known geographical distribution of canine heartworm in India. The distribution of heartworm in India extends from the Pakistani border in the west [51], Delhi and Sikkim in the north to the Burmese border in the east and Orissa to the south. The public health importance of $D$. repens also suggests that appropriate prophylaxis be administered to dogs throughout central and west India from as far south as Kerala to as far north as Delhi. From a diagnostic viewpoint, it is important to utilise an immunodiagnostic test that will not cross-react [8] between $D$. immitis and D. repens in areas where these two filarial species coexist, for example, Delhi.

\section{Acknowledgements}

Financial support for this study was provided by Bayer Animal Health. We gratefully thank our collaborators; Vets Beyond Borders, Jeevaashram, Krishnaashram and In Defense of Animal for their help with the fieldwork. Special thanks to David Spratt and Odile Bain for their very insightful information about Mf. auquieri, Jenny Seddon for her help with construction and interpretation of the phylogenetic results, Brian Bynon and Mark Roper for their help with slides staining process and Myat Kyaw-tanner for her help with molecular methods. PhD scholarship support for Puteri Azaziah Megat Abd Rani is provided by The Ministry of Higher Education, Malaysia. Publication of this thematic series has been sponsored by Bayer Animal Health $\mathrm{GmbH}$

\section{Author details}

${ }^{1}$ School of Veterinary Science, The University of Queensland, Queensland 4072, Australia. ${ }^{2}$ School of Veterinary and Biomedical Science, Murdoch University, Western Australia 6150, Australia. ${ }^{3}$ Bombay Veterinary College, Maharastra Animal and Fisheries Sciences University, Parel, Mumbai 400012, India.

\section{Authors' contributions}

PAMAR was involved in all phases of the study, including sampling and data collection, laboratory work, data analysis, intellectual interpretation, and writing the manuscript. RJT designed the study project, supervised the study, and was involved in sampling, field data collection, intellectual interpretation and critical revision of the manuscript for publication. LMM modified the DNA extraction method for FTA cards, construction and intellectual interpretation of the phylogenetic trees. PJI, MG and GTC supervised the study and were involved in intellectual interpretation and critical revision of the manuscript for publication. All authors read and approved the final manuscript.

\section{Competing interests}

The authors declare that they have no competing interests.

Received: 4 February 2010 Accepted: 8 April 2010

Published: 8 April 2010

\section{References}

1. Macpherson CN, Meslin FX, Wandeler Al: Dogs, Zoonoses and Public Health Anthony Rowe Limited, Eastbourne 2000.

2. Irwin PJ, Jefferies R: Arthropod-transmitted diseases of companion animals in Southeast Asia. Trends Parasitol 2004, 20:27-34.

3. Grieve RB, Lok JB, Glickman LT: Epidemiology of canine heartworm infection. Epidemiol Rev 1983, 5:220-246.

4. Kuecks RW, Slocombe JOD: Rapid histochemical differentiation of Dirofilaria immitis and Dipetalonema reconditum. Proceedings of the Heartworm Symposium; 23-24 February 1980; Dallas, Texas Otto GF 1980, 48-50.

5. Peribanez MA, Lucientes J, Arce S, Morales M, Castillo JA, Gracia MJ: Histochemical differentiation of Dirofilaria immitis, Dirofilaria repens and Acanthocheilonema dracunculoides microfilariae by staining with a commercial kit, Leucognost-SP (R). Vet Parasitol 2001, 102:173-175.

6. Ananda KJ, D'Souza PE, Jagannath MS: Methods for identification of microfilaria of Dirofilaria repens and Dipetalonema reconditum. J Vet Parasitol 2006, 20:45-47.

7. Atkins CE: Comparison of results of three commercial heartworm antigen test kits in dogs with low heartworm burdens. J Am Vet Med Assoc 2003, 222:1221-1223.

8. Ranjbar-Bahadori S, Eslami A, Bokaic S: Evaluation of different methods for diagnosis of Dirofilaria immitis. Pakistan J Bio Sci 2007, 10:1938-1940.

9. Rishniw M, Barr SC, Simpson KW, Frongillo MF, Franz M, Dominguez Alpizar $J$ L: Discrimination between six species of canine microfilariae by a single polymerase chain reaction. Vet Parasitol 2006, 135:303-314.

10. Casiraghi M, Bazzocchi C, Mortarino M, Ottina E, Genchi C: A simple molecular method for discriminating common filarial nematodes of dogs (Canis familiaris). Vet Parasitol 2006, 141:368-372.

11. Gogoi AR: Filarids of animals in India. J Vet Parasitol 2002, 16:131-138.

12. Dam T, Das P: The importance of dirofilariasis in India. Internet J Parasitic Dis 2006, 1.

13. Human filariasis parasite found in dogs. [http://www.hindu.com/2008/12/ 06/stories/2008120654580400.htm].

14. Sabu L, Subramanian $H$ : Prevalence and vector potentiality of mosquitoes from Thissur, Kerala. J Vet Parasitol 2007, 21:165-167.

15. Badhe BP, Sane SY: Human pulmonary dirofilariasis in India: a case report. J Trop Med Hyg 1989, 92:425-426. 
16. Supali T, Rahmah N, Djuardi Y, Sartono E, Rückert P, Fischer P: Detection of filaria-specific lgG4 antibodies using Brugia Rapid test in individuals from an area highly endemic for Brugia timori. Acta Trop 2004, 90:255-261.

17. Patz JA, Campbell-Lendrum D, Holloway T, Foley JA: Impact of regional climate change on human health. Nature 2005, 438:310-317.

18. Current weather forecast and climatological information - India. [http:// www.worldweather.org/066/m066.htm].

19. Current weather information - Gangtok. [http://imdsikkim.gov.in/]

20. Menezes R: Rabies in India. Can Med Assoc J 2008, 178:564.

21. Foley H: Microfilaires du chien dans le Sud-Oranais. Ann Inst Pasteur (Paris) 1921, 35:212-217.

22. Rioche M: Presence de Dipetalonema dracunculoides (Cobbold, 1870) chez le chien dans la region d'Alger. Arch Inst Pasteur Algér 1960, 38:386-398.

23. Casiraghi M, Anderson TJC, Bandi C, Bazzocchi C, Genchi C: A phylogenetic analysis of filarial nematodes: comparison with the phylogeny of Wolbachia endosymbionts. Parasitology 2001, 122:93-103.

24. Sabu L, Devada K, Subramanian H: Dirofilariosis in dogs \& humans in Kerala. Indian J Med Res 2005, 121:691-693.

25. Lai C-H, Tung K-C, Ooi H-K, Wang J-S: Susceptibility of mosquitoes in central Taiwan to natural infections of Dirofilaria immitis. Med Vet Entomol 2001, 15:64-67.

26. Cancrini G, Frangipane di Regalbono A, Ricci I, Tessarin C, Gabrielli S, Pietrobelli M: Aedes albopictus is a natural vector of Dirofilaria immitis in Italy. Vet Parasitol 2003, 118:195-202.

27. Tiawsirisup S, Kaewthamasorn M: The potential for Aedes albopictus (Skuse) (Diptera:Culicidae) to be a competent vector for canine heartworm, Dirofilaria immitis (Leidy). Southeast Asian I Trop Med Public Health 2007, 38:208-214.

28. Kumar NP, Rajavel AR, Natarajan $R$, Jambulingam P: DNA barcodes can distinguish species of Indian mosquitoes (Diptera: Culicidae). J Med Entomol 2009, 44:1-7.

29. Patnaik MM: On filarial nematodes in domestic animals in Orissa. Indian Vet J 1989, 66:573-574.

30. Borthakur SK, Sarmah K, Rajkhowa TK, Das MR, Rahman S: Dirofilaria immitis infection in dog. J Vet Parasitol 2006, 20:167-169.

31. Atwell RB: Basic pathophysiology and epidemiology in Australia. Heartworm symposium: Refresher course for veterinarians; 5 - 7 July 1988; Leura, NSW 1988, 36-43.

32. Weil GJ, Powers KG, Parbuoni EL, Line BR, Furrow RD, Ottesen EA: Dirofilaria immitis .6. Antimicrofilarial immunity in experimental filariasis. Am J Trop Med Hyg 1982, 31:477-485.

33. Elsadr WM, Aikawa M, Greene BM: In vitro immune-mechanisms associated with clearance of microfilariae of Dirofilaria immitis. J Immunol 1983, 130:428-434

34. Simón F, Morchón R, Gonzáles-Miguel J, Marcos-Atxutegi C, Siles-Lucas M: What is new about animal and human dirofilariosis? Trends Parasitol 2009, 25:404-409.

35. Touré $\mathrm{FS}$, Bain $\mathrm{O}$, Nerrienet $\mathrm{E}$, Millet $\mathrm{P}$, Wahl $\mathrm{G}$, Toure $\mathrm{Y}$, Doumbo $\mathrm{O}$, Nicolas L, Georges AJ, McReynolds LA, Egwang TG: Detection ofLoa loaSpecific DNA in Blood from Occult-Infected Individuals. Exp Parasitol 1997, 86:163-170.

36. Touré FS, Mavoungou E, Kassambara L, Williams T, Wahl G, Millet $P$, Egwang TG: Human occult loiasis: field evaluation of a nested polymerase chain reaction assay for the detection of occult infection. Trop Med Int Health 1998, 3:505-511.

37. Duscher G, Peschke R, Wille-Piazzai W, Joachim A: Parasites on paper - The use of FTA Elute ${ }^{\oplus}$ for the detection of Dirofilaria repens microfilariae in canine blood. Vet Parasitol 2009, 161:349-351.

38. Bazzocchi C, Mortarino M, Grandi G, Kramer LH, Genchi C, Bandi C, Genchi M, Sacchi L, McCall JW: Combined ivermectin and doxycycline treatment has microfilaricidal and adulticidal activity against Dirofilaria immitis in experimentally infected dogs. Int J Parasitol 2008, 38:1401-1410.

39. Pampiglione S, Rivasi F: Human dirofilariasis due to Dirofilaria (Nochtiella) repens: an update of world literature from 1995 to 2000. Parassitologia 2000, 42:231-254.

40. Huynh T, Thean J, Maini R: Dipetalonema reconditum in the human eye. $B r$ J Ophthalmol 2001, 85:1391.

41. Theis JH: Public health aspects of dirofilariasis in the United States. Vet Parasitol 2005, 133:157-180.
42. Foroulis CN, Khaldi L, Desimonas N, Kalafati G: Pulmonary dirofilariasis mimicking lung tumor with chest wall and mediastinal invasion. Thorac Cardiovasc Surg 2005, 53:173-175.

43. Dobson C, Welch JS: Dirofilariasis as a cause of eosinophilic meningitis in man diagnosed by immunofluorescence and arthus hypersensitivity. Trans R Soc Trop Med Hyg 1974, 68:223-228.

44. Moorhouse DE: Dirofilaria immitis: A cause of human intra-ocular infection. Infection 1978, 6:192-193.

45. Tada I, Sakaquchi Y, Eto K: Dirofilaria in the Abdominal Cavity of a Man in Japan. Am J Trop Med Hyg 1979, 28:988.

46. Theis JH: Case report: Unusual location of Dirofilaria immitis in a 28-yearold man necessitates orchiectomy. Am J Trop Med Hyg 2001, 64:317-322.

47. Kim MK, Kim CH, Yeom BW, Park SH, Choi SY, Choi JS: The first human case of hepatic dirofilariasis. J Korean Med Sci 2002, 17:686-690.

48. Areekit $S$, Singhaphan $P$, Khucareontaworn $S$, Kanjanavas $P$, Sriyaphai $T$, Pakpitchareon A, Khawsak P, Chansiri K: Intraspecies variation of Brugia spp. in cat reservoirs using complete ITS sequences. Parasitol Res 2009, 104:1465-1469.

49. Bequaert J: Notes on Hippoboscidae 2. The subfamily Hippoboscinae. Psyche (Stuttg) 1930, XXXVII:303-326.

50. Nelson GS: Dipetalonema drancunculoides (Cobbold, 1870), from the dog in Kenya: wth a note on its development in the louse-fly, Hippobosca longipennis. J Helminthol 1963, 37:235-240.

51. Wolfe MS, Aslamkhan M, Sharif M, E P: Acanthocheilonema dracunculoides (Cobbold, 1870) in dogs in Lahore, West Pakistan. J Helminthol 1971, 45:171-176.

52. Chakravarty A, Chaudhuri MN: Studies on canine filariasis in West Bengal. Indian J Anim Health 1983, 22:151-155.

53. Lapage G: Veterinary Helminthology and Entomology London: Bailliere, Tindall and Cox, 41956.

54. Chakravarty A, Chaudhuri MN: Developmental stages of Brugia pahangi in the final host. J Parasitol 1962, 48:693-706.

doi:10.1186/1756-3305-3-30

Cite this article as: Megat Abd Rani et al:: A survey of canine filarial diseases of veterinary and public health significance in India. Parasites \& Vectors 2010 3:30

\section{Submit your next manuscript to BioMed Central and take full advantage of:}

- Convenient online submission

- Thorough peer review

- No space constraints or color figure charges

- Immediate publication on acceptance

- Inclusion in PubMed, CAS, Scopus and Google Scholar

- Research which is freely available for redistribution
Ciomed Central 